\title{
UJI HIDRODINAMIKA DESAIN DERMAGA APUNG MODULAR SEBAGAI TEKNOLOGI ALTERNATIF DALAM MEMBANGUN DERMAGA PERINTIS DI INDONESIA BAGIAN TIMUR
}

\author{
Prio Sasoko ${ }^{1}$, Abdul Ghofur², Budi S. Prasodjo $^{3}$, Bambang Wijanarko ${ }^{4}$ \\ UPT-BPPH BPP Teknologi \\ Jl. Hidrodinamika, Kompleks ITS, Surabaya60112 \\ Telepon (031) 5948060 \\ e-Mail : prio.sasoko@bppt.go.id
}

Dermaga merupakan prasarana transportasi laut yang sangat vital, akan tetapi kondisi dermaga-dermaga di daerah perintis kebanyakan kurang layak dan dibangun dengan kondisi yang sangat terbatas karena keterbatasan dana pembangunan dari daerah tersebut. Daerah dengan kondisi alam yang tergolong ekstrim dimana sering terjadi gempa bumi, memiliki perbedaan pasang surut yang tinggi serta kondisi dasar perairan yang berlumpur mengakibatkan pembangunan dan pengembangan dermaga konvensional dengan konstruksi kayu ataupun beton tidak menguntungkan. Hal ini menyebabkan kebutuhan akan suatu konsep desain dermaga terapung modular, terutama untuk daerah perintis dan wisata sebagai salah satu teknologi alternatif yang memiliki beberapa kelebihan dari teknologi konvensional dermaga beton yang ada. Sebagai sebuah media, dermaga terapung akan menerima pembebanan dari tumpukan barang dan penumpang serta fasilitas yang ada di atasnya yang menekan konstruksi ke bawah, sementara dari arah berlawanan konstruksi mengalami pembebanan berupa gaya gelombang, arus dan tumbukan kapal yang diterima oleh struktur teraung dan juga didistribusikan ke tiang pancang yang mengikat struktur terapung. Efek efek tersebut akan menjadi fokus dari riset ini dimana karakteristik hidrostatik akan dianalisa terlebih dahulu untuk mendapatkan ukuran utama struktur dermaga terapung yang akan didesain.

Kata Kunci : dermaga, dermaga apung, dermaga modular, tahan gempa, ramah lingkungan

\footnotetext{
${ }^{1}$ MT., M.Sc. BSEE, Prio Sasoko, staf UPT-BPPH BPP Teknologi

${ }^{2}$ M.Sc., Ir., Abdul Ghofur, staf UPT-BPPH BPP Teknologi

${ }^{3}$ Ph.D, M.Eng., ST., Budi Setyo Prasofjo, staf UPT-BPPH BPP Teknologi

${ }^{4} M$.Eng., Ing., Bambang Wijanarko, staf UPT-BPPH BPP Teknologi
}

\section{Pendahuluan}

Pembangunan ataupun peremajaan dermaga dermaga bukanlah hal yang mudah dan murah. Di lain pihak, keterbatasan lahan dan kondisi alam yang kurang menguntungkan merupakan masalah tersendiri dalam pembuatan dan pengembangan pelabuhan. $\mathrm{Di}$ beberapa daerah di Indonesia meskipun keterbatasan lahan belum merupakan masalah yang serius, namun ada daerah dengan kondisi alam yang tergolong ekstrim dimana sering terjadi gempa bumi, memiliki perbedaan pasang surut yang tinggi serta kondisi dasar perairan yang berlumpur mengakibatkan pembangunan dan pengembangan pelabuhan konvensional dengan konstruksi kayu ataupun beton tidak menguntungkan 
Dengan melihat besarnya tantangan dan peluang yang ada sebagaimana disebutkan di atas, penelitian ini mencoba mengkaji suatu konsep desain dari dermaga terapung modular untuk pelabuhan, terutama untuk daerah perintis dan wisata sebagai salah satu teknologi alternatif yang dalam kondisi tertentu memiliki beberapa kelebihan dari teknologi konvensional pelabuhan beton yang ada.

\section{Dermaga Apung Modular}

Dermaga Apung Modular (DAM) adalah sebuah konsep dermaga yang terapung yang dibangun dengan menyusun kotak-kotak yang dibuat dengan bahan High Density Polyethelyne (HDPE) yang dinamakan Floaton.

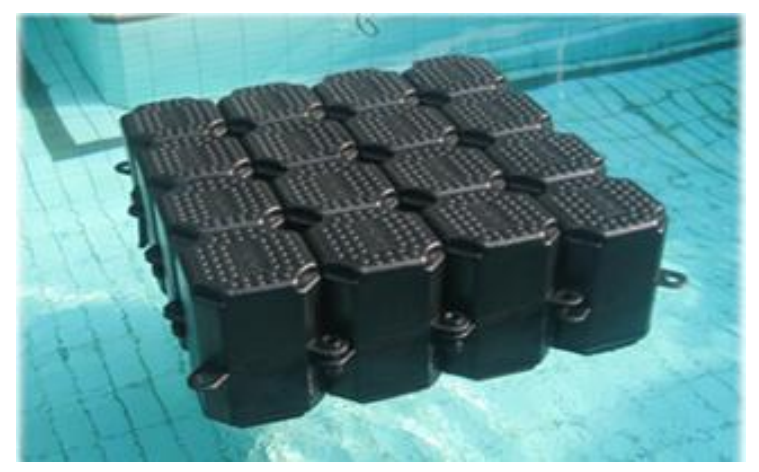

Gambar 1: floaton sbg bahan dasar $D A M$

Beberapa keunggulan yang dimiliki dermaga terapung modular antara lain dimensi dan bentuk bisa fleksibel karena bisa bongkar pasang dengan system modular, dinamis sehingga bisa dipindah tempat atau digeser sehingga memungkinkan untuk dijadikan pelabuhan perintis pada pulau-pulau terpencil dan daerah pedalaman, dapat mengikuti perubahan pasang surut sehingga water level antara pelabuhan dan kapal bisa dipertahankan dalam kondisi apapun, konstruksinya sederhana, waktu pembuatannya lebih singkat, tahan terhadap gempa, ramah lingkungan, dapat digunakan untuk perairan dengan elevasi pasang surut air laut yang besar, relatif murah, terhindar dari sedimentasi, perakitan di darat dan untuk daerah yang memiliki daya dukung tanah rendah.

\section{Pengujian Laboratorium}

Pengujian laboratorium perlu dilakukan untuk dapat memprediksi kinerja DAM dalam masa operasionalnya. Pengujian laboratorium ini dapat dipakai sebagai pembanding dan validasi hasil analisa numerik yang sebelumnya telah dilakukan dengan memakai komputer. Beberapa pengujian yang telah dilakukan adalah:

- Uji pembebanan

- Uji redaman gaya impact

- Uji gelombang

- Uji benturan kapal

Pengujian dilakukan di kolam dangkal dari Manoeuvering Ocean Engineering Basin, Laboratorium Hidrodinamika Indonesia dengan memakai model floaton dengan skala 1:10 


\section{Uji pembebanan DAM}

Pengujian dilakukan dengan melakukan variasi pembebanan dengan skala 1:1000 untuk model DAM skala 1:10

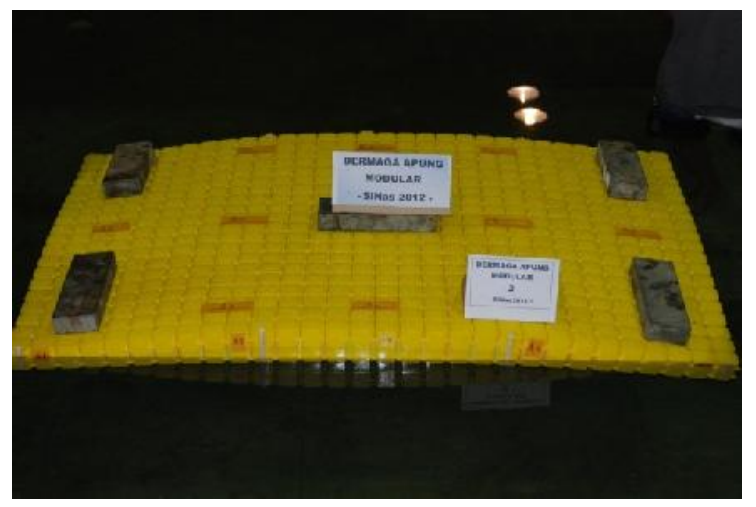

Gambar 2: Uji beban 50kg (50 ton)

Tabel 1: hasil uji beban

\begin{tabular}{|l|r|l|}
\hline Box $50 \times 50 \times 40 \mathrm{~cm}$ & 6 & $\mathrm{Kg}$ \\
\hline Berat & 4 & $\mathrm{Box}$ \\
\hline $1 \mathrm{~m} 2-1$ Layer & 24 & $\mathrm{Kg}$ \\
\hline & 40 & $\mathrm{~cm}$ \\
\hline Tinggi & & \\
\hline & 8 & $\mathrm{Box}$ \\
\hline $1 \mathrm{~m} 2-2$ Layer & 48 & $\mathrm{Kg}$ \\
\hline & 80 & $\mathrm{~cm}$ \\
\hline Tinggi & 30 & $\mathrm{Kg}$ \\
\hline GRC $1 \mathrm{~m} 2$ & 78 & $\mathrm{Kg} / \mathrm{m} 2$ \\
\hline Berat Box $+\mathrm{GRC}$ & $-7,8$ & $\mathrm{~cm}$ \\
\hline Beban & 72,2 & $\mathrm{~cm}$ \\
\hline Draft $80 \mathrm{~cm}-7,8 \mathrm{~cm}$ & & \\
\hline & 12 & $\mathrm{~m} 2$ \\
\hline Konstruksi $2 \mathrm{~m} \times 6 \mathrm{~m}$ & 8664 & $\mathrm{Kg}$ \\
\hline Daya Apung Max $72,2 \mathrm{~cm} \times 10 \mathrm{Kg} / \mathrm{m} 2 \times 12 \mathrm{~m} 2$ & & \\
\hline
\end{tabular}

\section{Uji Redaman DAM}

Sebelum pengujian dengan gelombang dilakukan, dibutuhkan satu macam pengujian di darat yaitu pengujian redamam model dermaga apung modular untuk mendapatkan koefisien redaman dari Dermaga Apung tersebut. Koefisien redaman ini akan digunakan untuk menghitung gaya impact yang terjadi pada tiang pancang akibat benturan kapal yang dialami oleh Dermaga Apung tersebut.

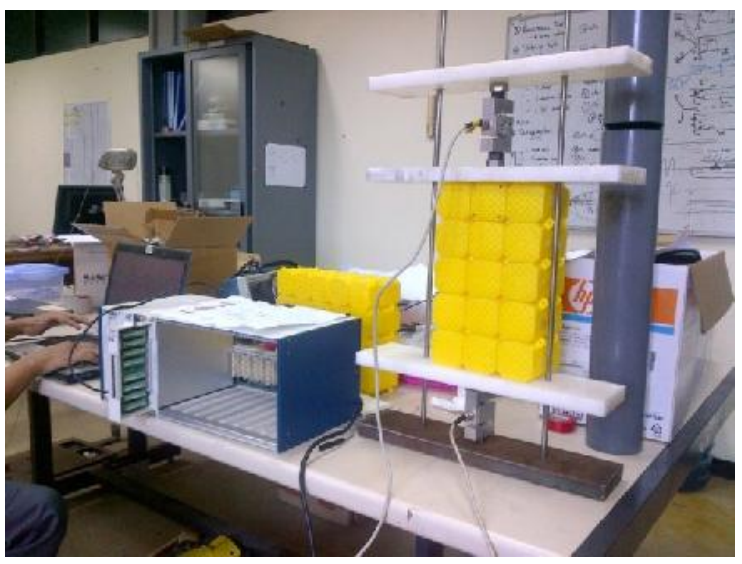

Gambar 3: Uji Redaman gaya impact

Tabel 2: hasil uji redaman

\begin{tabular}{|l|r|r|r|}
\hline & \multicolumn{1}{|c|}{$\begin{array}{l}\text { Jumlah } \\
\text { DAM }\end{array}$} & $\begin{array}{l}\text { Rata-rata } \\
\text { gaya Impact }\end{array}$ & $\begin{array}{l}\text { Persentasi } \\
\text { Redaman }\end{array}$ \\
\hline Load Cell atas & 1 & 95,09754 & 8,38 \\
\hline Load Cell bawah & 1 & 87,13046 & \\
\hline Load Cell atas & 2 & 94,24599 & 18,19 \\
\hline Load Cell bawah & 2 & 77,80169 & \\
\hline Load Cell atas & 3 & 95,19162 & 25,57 \\
\hline Load Cell bawah & 3 & 70,78212 & \\
\hline Load Cell atas & 4 & 94,03261 & 31,52 \\
\hline Load Cell bawah & 4 & 65,11959 & \\
\hline
\end{tabular}

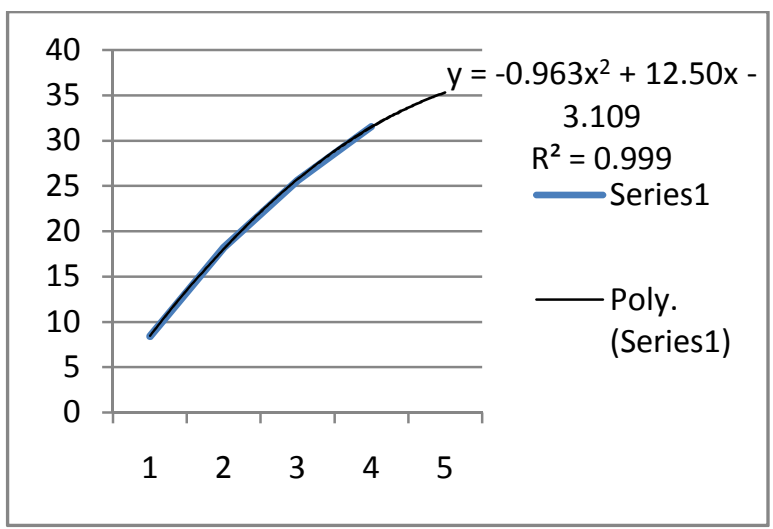

Gambar 4: Persamaan koefisien redaman 


\section{Uji variasi gelombang}

Pengujian variasi gelombang dilakukan dengan dua macam variasi yaitu gelombang pendek dan gelombang panjang yang merepresentasikan kondisi gelombang ekstrim yang kemungkinan dialami oleh sebuan dermaga apung.

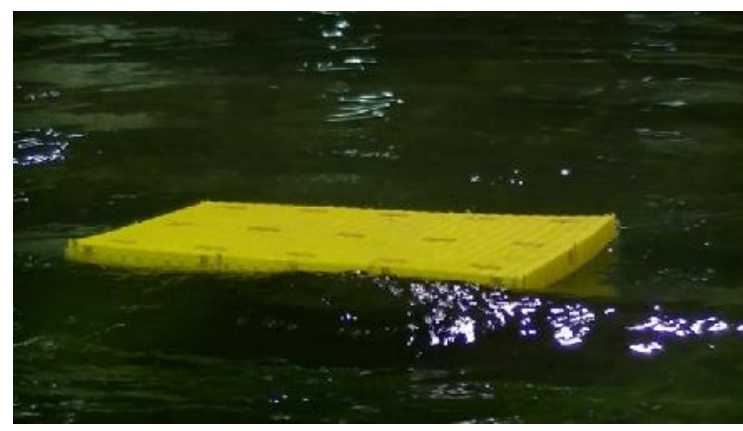

Gambar 5: uji DAM tipe tambat

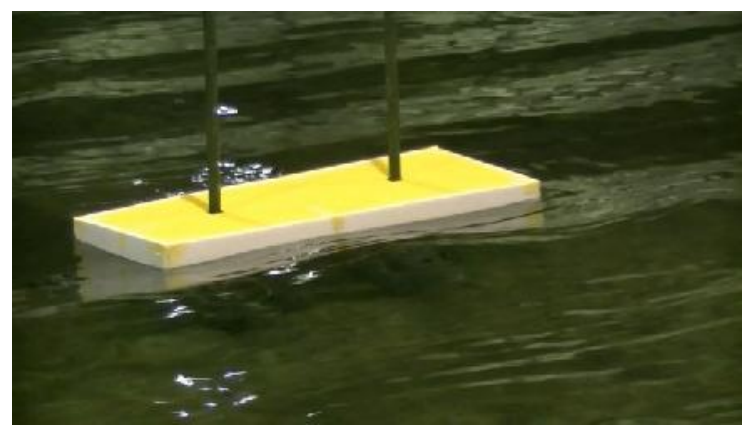

Gambar 6: uji DAM tipe pancang

Hasil pengukuran gaya gelombang pada tepi dermaga adalah $7499 \mathrm{~N} / \mathrm{m}$

\section{Uji gaya impact kapal}

Pengujian terakhir adalah pengujian benturan kapal. Data yang diambil adalah data gaya impact benturan kapal yang akan menentukan kekuatan dari tali tambat yang akan digunakan pada DAM tipe tambat dan yang akan menentukan kekuatan tiang pancang yang akan digunakan pada DAM tipe pancang. Data untuk pengujian DAM tipe tambat dapat secara langsung diperoleh dengan memasang load cell pada tali tambat sehingga gaya tension akibat benturan kapal dapat direkam. Sedangkan untuk DAM tipe pancang, pengaruh yang dirasakan tiang pancang akan diturunkan dari gaya impact yang dihitung dari massa dan kecepatan kapal dan dengan memakai koefisien redaman yang telah diperoleh dapat diturunkan gaya impact pada tiang pancang.

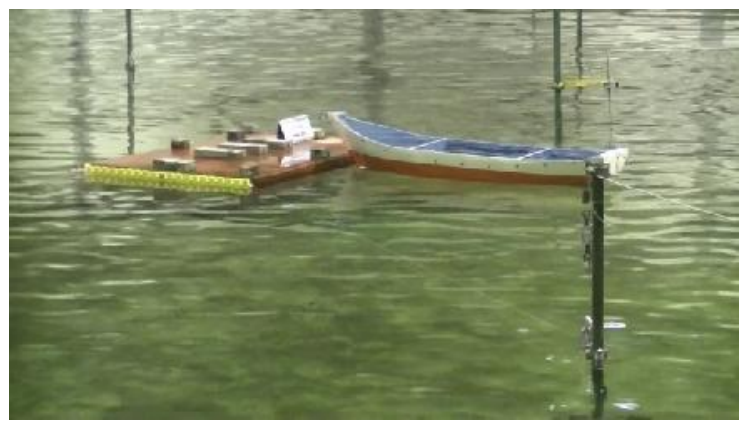

Gambar 7: DAM tipe tambat

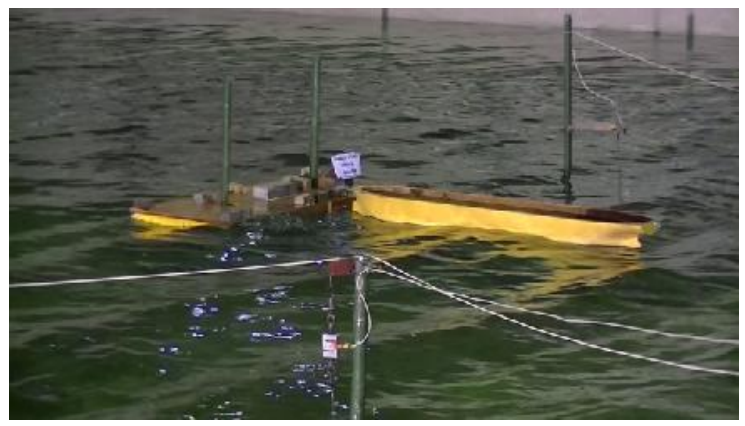

Gambar 8: DAM tipe pancang 
Tabel 4: hasil uji gaya impact

\begin{tabular}{|c|c|c|c|}
\hline \multicolumn{2}{|c|}{\begin{tabular}{|r|} 
Parameter \\
\end{tabular}} & Nilai & Satuan \\
\hline \multicolumn{2}{|c|}{ Tonase Mati Kapal } & 32 & DWT \\
\hline \multicolumn{2}{|c|}{ displacement } & 86 & ton \\
\hline \multicolumn{2}{|c|}{ Length overall } & 20 & $\mathrm{~m}$ \\
\hline \multicolumn{2}{|c|}{ Molded` breadth } & 4 & $\mathrm{~m}$ \\
\hline \multicolumn{2}{|c|}{ Full load draft } & 1.5 & $\mathrm{~m}$ \\
\hline \multicolumn{2}{|c|}{ ballast draft } & 0.9 & $\mathrm{~m}$ \\
\hline \multicolumn{2}{|c|}{ Depth } & 3.5 & $\mathrm{~m}$ \\
\hline \multicolumn{2}{|c|}{ full load freeboard } & 2 & $m$ \\
\hline \multicolumn{2}{|c|}{ ballast freeboard } & 2.6 & $\mathrm{~m}$ \\
\hline \multirow{2}{*}{ ballast } & wind lateral area & 51 & $\mathrm{~m} 2$ \\
\hline & wind front area & 10 & $\mathrm{~m} 2$ \\
\hline \multirow{2}{*}{ full } & wind lateral area & 40 & $\mathrm{~m} 2$ \\
\hline & wind front area & 8 & $\mathrm{~m} 2$ \\
\hline \multicolumn{2}{|c|}{ V angin } & 25 & $\mathrm{~m} / \mathrm{s}$ \\
\hline \multicolumn{2}{|c|}{ V arus } & 1 & $\mathrm{~m} / \mathrm{s}$ \\
\hline \multicolumn{2}{|c|}{$\mathrm{Qa}$} & 39.4 & $\mathrm{~kg} / \mathrm{m} 2$ \\
\hline \multicolumn{4}{|c|}{ angin } \\
\hline \multirow{3}{*}{ ballast } & Rw haluan & 0.2 & ton \\
\hline & Rw buritan & 0.2 & ton \\
\hline & Rw samping & 2.2 & ton \\
\hline \multirow{3}{*}{ full } & Rw haluan & 0.1 & ton \\
\hline & Rw buritan & 0.2 & ton \\
\hline & Rw samping & 1.7 & ton \\
\hline \multicolumn{4}{|c|}{ arus } \\
\hline \multirow{2}{*}{ ballast } & Rf haluan & 0.001 & ton \\
\hline & Rf samping & 4.8 & ton \\
\hline \multirow{2}{*}{ full } & Rf haluan & 0.001 & ton \\
\hline & Rf samping & 7.7 & ton \\
\hline \multicolumn{4}{|c|}{ gaya tarikan kapal total } \\
\hline \multirow{2}{*}{ balast } & muka & 0.20 & ton \\
\hline & samping & 7.04 & ton \\
\hline \multirow{2}{*}{ full } & muka & 0.16 & ton \\
\hline & samping & 9.42 & ton \\
\hline
\end{tabular}

\section{Kesimpulan}

Dari rangkaian pengujian di atas dapat disimpulkan bahwa DAM dengan bahan dasar floaton dapat berfungsi dengan bagus sebagai dermaga untuk skala dermaga perintis, kecil sampai menengah.

\section{Dartar Pustaka}

1. Budi S. Prasodjo, "Potency and Challenge of Composite Material for Marine Structure", Journal of Industrial Assessment - BPPT, vol. 11, August 2000, pp. 1-6

2. Budi S. Prasodjo, Kimio Saito, "Dynamic Responses of Multi Modules Floating System Connected with Elastic Rubbers", $9^{\text {th }}$ Symposium on Non-linear and FreeSurface Flows, Hiroshima-Japan, December 2003, pp.91-94.
3. Budi S. Prasodjo, Kimio Saito, Hisashi Nobukawa, "Study on Elastic Responses in Waves of Modular Floating System with Flexible Joint-In Case of Unit Module", Transactions of the West Japan Society of Naval Architects, No.108, August 2004, pp. 191-201.

4. Budi S. Prasodjo, Kimio Saito, Hisashi Nobukawa, "On the Elastic Responses of Multi Modules Floating System", Proceeding of the 13th Indonesian Scientific Meeting, Tokyo-Japan, September 2004, pp. 141-147.

5. Prasodjo, B.S., Saito, K., Nobukawa, H., Maeda, K., "Elastic Responses in Waves of Modular Floating System with Flexible Connection", $18^{\text {th }}$ Ocean Engineering Symposium, Tokyo, Japan (2005).

6. Budi S. Prasodjo, Kimio Saito, Hisashi Nobukawa, Katsuya Maeda, "Study on Elastic Responses in Waves of Modular Floating System with Flexible Joint $\left(2^{\text {nd }}\right.$ report)- Deflection of floating structure in waves", Transactions of the West Japan Society of Naval Architects, No.109 March 2005, pp. 1-11.

7. Budi S. Prasodjo, Kimio Saito, Yasushi Higo, Hisashi Nobukawa, "Bending Moment of Different Connector Stiffness for Modular Floating System", Proceeding of the 14th Indonesian Scientific Meeting, Nagoya-Japan, September 2005, pp.543550.

8. Kimio Saito, Budi S. Prasodjo, Yasushi Higo, Hisashi Nobukawa, Katsuya Maeda, Akihito Matsuda, Mitsunori Uchida, "Study on Coastal Cargo Ship Consisting of Unit Modules, - Vertical Motions of Units and Connecting Forces in Oblique Waves-", Journal of The Japan Society of Naval Architects and Ocean Engineers (JASNAOE), Vol. 3, June 2006, pp. 167175. 